\title{
Wow factors - Securing local authority support
}

Received (in revised form): 31 January 2006

\section{Tom Macartney}

is Chief Executive of Sunderland ARC, one of the urban regeneration companies established by the government to create step-change in key urban areas. Among his major previous roles was that of Director of the multi-award winning Crown Street in Gorbals, Glasgow - now one of the most popular residential areas in that rapidly regenerating city.

\begin{abstract}
Every city needs something special, distinctive elements by which the city will be known and identified throughout the world. Such 'wow factors' may be historical monuments, iconic works of architecture (old or new), or the cumulative effect of moments of sculptural magic woven into the fabric of buildings, streets and spaces. These elements differentiate cities one from the other and serve fundamental social, cultural and economic roles. However, achieving the 'wow' requires the engagement of our sometimes reluctant modern-day Medicis - the local authorities. This paper addresses the key issue of persuading local authorities to buy into the wow factor.
\end{abstract}

\section{Keywords:}

wow factors, local authorities, grande projects, transformation, symbols, civic pride, risk

Journal of Retail and Leisure Property (2006) 5, 219-225. doi:10.1057/palgrave.rlp.5100021

\section{LOCAL AUTHORITIES AND WOW - A CONTRADICTION IN TERMS?}

All of us rely on local government to deliver key services. Our local authorities deliver education to our children, support to those in need and crucial elements of urban infrastructure from road building to street cleaning. They even empty the bins! All this is both vital and costly.

Of course, local authorities also contribute substantially to the physical, emotional and cultural well-being of individuals through their provision of sporting facilities, parkland space, museums/galleries and performance venues. Yet, this diverse range of demands upon the public purse

Tom Macartney Sunderland Arc North Sands Business Centre Liberty Way Sunderland SR6 OQA, UK Tel: + 441915689880 Fax: + 441915657961 Email: tom@sunderlandarc.co.uk overlooks another factor, which is fundamental to ensuring the success of cities - delight!

Mention the idea of commissioning a major work of art or finding the significant additional spend that will transform a new building from prosaic to world class and most local councillors will immediately give ten good reasons not to. Local authorities are, by their very nature, risk averse. Balancing the budget is tough enough without opening themselves 
up to the criticism of indulgence. However, procurement patterns over the last half-century or so have shifted. Art is no longer the province of the elite. It has become a public procurement issue. And the problem for our cities is - if the local authorities will not, who will?

\section{CHANGING ROLES - COMMISSIONING 'WOW'}

In the past the city fathers, ecclesiasts, merchants and businessmen commissioned monuments, memorial statuary and architectural embellishment which enlivened the streets, squares and parklands of cities. This extraordinary panoply of monuments celebrated figures whose achievements, whether martial, political, social or artistic, were deemed worthy of permanent reminders. Throughout the UK, buildings, particularly those from the latter half of the 19th and the first half of the 20th century, bear a weight of symbolism and mythology wrought in stone, which is an extraordinary and enduring demonstration of selfworth.

The Victorians in particular understood that while creating a large building might take wealth, covering it with decorative detail and statuary denotes both self-confidence and the peacock display of the very rich. Throughout the long period of the UK's great industrial wealth, many of the magnates who were the greatest beneficiaries of industrial growth invested a proportion of their extraordinary gains in works of civic virtue. They endowed great buildings, elements of infrastructure (particularly fine bridges) and the fountains and statuary, which embellish our parkland and civic squares. They were well aware of the functional necessity of many of their works, but equally determined that people should take note both of their achievements and of their standing in their own community.

The 20th century fundamentally altered the power structure, which determines how change is wrought within our cities. Businesses of course still fund new buildings even, on occasion, works of statuary and the sculptural embellishment of our streets and public spaces. However, relatively few big businesses remain in the hands of individuals or families. Legal strictures and the need to answer to shareholders have fundamentally altered the historic relationship between business and the arts.

No one would question that the onus for creating new civic works now rests predominately with our local authorities. They sit at the heart of the regeneration process. They control land. They allow the creation of new buildings and exercise control over their form. The local authorities let road contracts and will use their own investment programmes to further regeneration aims. They occupy and control much new development. Simply put, without local government support, very little can happen, this is particularly true of projects that introduce the additional element that transcends utility — the wow factor!

\section{GRANDE PROJECTS - NECESSITY OR INDULGENCE?}

Big impact projects provide useful symbols. Not only should they be, of themselves, visitor attractions, but they provide the imagery for tourism 
brochures. They are the gaudy fly on the hook which reels us (and our invaluable pound, euro, dollar or yen) in to one city as opposed to another.

Yet once visitors have been reeled in, there are other crucial elements beyond the utilitarian which will ensure a repeat visit or, where business is concerned, the ultimate goal - a decision to settle. There are of course those aspects of infrastructure and service delivery that must at least be adequate, preferably of some quality, to maximise the attraction of the place and what the tourism industry refers to as 'dwell time'. However, securing the ultimate long-term dwell time of permanent residence requires that the city, an organism of extraordinary complexity, retains its dynamism. The successful city is a lively and varied place that combines efficient services with regular infusions of new delight.

Considering, for a moment, the structures we associate with a number of major cities might help focus the argument. Paris, almost by default, is the beneficiary of Gustave Eiffel's 1889 monument to his own engineering genius. This was a monument which, incidentally, was reviled by most of Eiffel's Parisian contemporaries and almost bankrupted Eiffel himself. Happily he did recover financially and a company bearing his name continues to undertake major engineering works to this day.

Another French invention became one of the first symbols of New York. The Statue of Liberty, the creation of a mad genius French sculptor (the internal armature is by Eiffel) superceded Brooklyn Bridge as the great symbolic monument of that city. It is worthy notingthat while the bridge had a very obvious function as the first permanent connection between Brooklyn and Manhattan, the statue is a purely symbolic gesture marking the shared emphasis on liberty in the French and American constitutions.

In much the same way as Liberty succeeded the Brooklyn Bridge, so Sydney Opera House succeeded the Harbour Bridge. It is arguable that here, once again, something of obvious utility was replaced in the public perception as Sydney's most notable wow attraction by a creation of purely cultural significance.

This point is emphasised by the fact that Sydney's is an opera house of very questionable usefulness. The building has insufficient capacity for staging most operatic performances and really only serves as a concert hall. However, what the Sydney building does emphasise is the potential of the extraordinarily dramatic structure to very rapidly assume iconic status. Indeed, within a very short time this success allowed Sydney's city fathers to overlook the fact that, when complete, the building was nearly 2000 per cent over the original cost plan.

The city which is arguably the most notable for the continuous generation of iconic structures is the birthplace of Monsieur Eiffel's tower - Paris. Lord Palumbo once commented that the difference between the French and the British was that in London, if the idea for a great iconic structure came along it would, nine times out of ten, be killed off by the process of economic assessment. Paris, on the other hand, presented with half a dozen good ideas, would build them all.

Thus, the Centre Pompidou became the first of a whole series of recent Parisian monuments and the first of a succession of grande projets, which 
have stimulated French tourism for the past three decades. In fact, for a long period it was Piano and Roger's 1977 Pompidou Centre and not M. Eiffel's tower, which served as the single most important tourist draw in Paris and indeed the most visited building in Europe. Nearly 30 years on, it is still in the top ten!

Of course, there is a necessary corrective to all of this acclamation for major iconic projects. The Millennium Dome is quite a structure, but as the political fall-out from the process of its creation indicated it certainly did not produce a balanced equation where public perception, delight and renewed enthusiasm for London countered the large and oft-quoted cost considerations.

Then there is the Atomium. Brussels' 1958 answer to the Eiffel Tower is frequently cited as the most risible building in Europe. Doubtless, it has a major appeal to sci-fi anoraks but it has never really assumed any ranking among world monuments and it would be highly unlikely to be quoted by a visitor to Brussels as their reason for the trip.

So it is quite possible to get it wrong, but then the old adage "nothing ventured, nothing gained' is as true for major totemic works of engineering and architecture as for any other human activity. There's always risk.

\section{SPANISH LESSONS}

A comparison of Spanish cities indicates two approaches, both of which have worked and which certainly represent positive examples, which others would do well to emulate. The Catalan capital, Barcelona, is the beneficiary of all of Antoni Gaudi's great works. This hugely eccentric architect somehow reinvented stone as a material of extraordinary plasticity. He bequeathed a number of major residential projects, grand individual houses and apartment blocks and, of course, the fabulous Sagrada Familia. Only one end and part of the nave of Gaudi's cathedral was complete upon its author's untimely accidental death. In recent years, the change in the city's fortunes has been reflected in the accelerated process of completing the Sagrada, which is now scheduled to open around the year 2025 .

Apropos the other major Gaudi legacy, the Parc Guell, it is interesting to note that this, like Eiffel's tower, was never intended as a long-term contribution to the well-being of a broad public. Rather, Count Guell anticipated an exclusive enclave of luxurious villas for the very wealthy. Gaudi made the mistake of creating a parkland setting in advance of building the houses that so delighted his client and a number of senior figures at City Hall that the former changed his plans and gifted the extraordinary landscape to the city.

Yet, even with all of Gaudi's creativity, Barcelona's fortunes as a tourism destination only really took off with the city's reinvention of itself post 1975. That year saw the death of Franco who had determinedly repressed the Catalan people. He had banned their native language, restricted cultural expression and prevented infrastructural and economic development. 
Soon after Franco's demise, the City Fathers seconded Oriel Bohigas from one of the city's most creative architectural practices Martorell, Bohigas, Mackay (MBM) to help in the process of redesigning central Barcelona. Bohigas created a whole series of civic spaces, which allowed this densely inhabited city to lead much more of its leisure on the streets in squares, pavement cafés and new parks.

This infrastructural change combined with a new freedom to develop led to unprecedented growth. Of course, it was the 1992 Olympic Games that finally focused the attention of the world on Barcelona. Since then, its fortunes as a tourism visitor destination and a location for new business and industrial settlement have continued to rise.

A relative arriviste in the great game of urban redefinition by the creation of new monuments is Bilbao. Here, Frank Gehry's Guggenheim Museum, which opened in 1997 is undoubtedly the star attraction among a series of commissions from leading world architects. These include the new airport by Santiago Calatrava, a new conference and performing arts centre and a new underground railway by Sir Norman Foster.

Gehry's building, set in the very centre of the city, runs down to the waterside of the Nervion River. One end of the building is cut through by Bilbao's main arterial roadway, the Puente de la Salve.

Bilbao is a city transformed. From being completely off the tourism radar, it is now, like Barcelona, a hugely popular destination. However, the difference is that Barcelona has marketed its existing attractions and concentrated more on infrastructure and delivery while Bilbao, with less historical qualities to build upon, has determinedly promoted a dynamic new image based on powerful contemporary architectural forms.

\section{CLOSER TO HOME}

London too has recognised that great cities require continuous dynamism and change. The London Eye and Foster's new Gherkin, an extraordinary reinvention of City Hall, are both 'wow' structures. They emphasise modernity and that the city is moving, changing and presenting new attractions to visitors and investors.

On a more modest scale than the great European monuments referred to above, Gateshead has been giving a very good North East of England impersonation of Paris in recent years by building every good idea that comes along. The process started with Anthony Gormley's fabulous Angel of the North, the new symbol of the North East. It appears constantly on television and its very visibility from road and rail ensures continuous reinforcement of its iconic status with very large numbers of the general public.

Gormley's iconic structure is an indicator of a local authority that, through its enlightened patronage of major projects, has generated huge interest and significantly boosted the economy. The remarkable and accelerated growth of commercial activity and the creation of a vibrant new leisure district on both sides of the River Tyne demonstrate that this is an area that is redefining itself as a vibrant and diverse destination. Wilkinson Eyre's Millennium Bridge, Ellis Williams Architects' remarkable conversion of the Baltic Flour Mill as a Centre for 
Contemporary Art and the Sage, Lord Foster's extraordinary curvilinear new music venue on the banks of the Tyne, further emphasise the message.

\section{GETTING LOCAL AUTHORITIES ON-SIDE}

As all of the above argues, contemporary economics require that local authorities get on-side in the process of generating the 'wow factor' for our cities. As has already been observed, the wow factor is not necessarily all about major totemic structures. The symbolic buildings and monuments by which a place is universally recognised are hugely important, but they are by no means the only focus of this discourse.

Local authorities may as in Crown Street, Glasgow, simply endorse a process whereby developers are coerced into investing in art, which enlivens the streets and buildings of a new community (a process which incidentally persuaded most of the developers that public art helped in the process of selling houses). The cumulative effect is a new outdoor gallery, enhancing the attraction of the place. Alternatively, local authorities may, like Gateshead or Paris, decide that they can re-define their place by creating major new icons. However, they do have to be persuaded that for civic health the 'wow factor' is not an option but a necessity.

The question of how local authorities might be persuaded of this necessity is another matter. Perhaps it is in the semantics. The 'wow factor' sounds like a risk. The terminology is just too rich for the evercautious local politician. Perhaps changing the emphasis to 'civic pride' is one answer. Good councillors are dedicated to public service and fiercely proud of their home towns. They constantly extol the virtues of the local environment and praise the endeavour of local people. Iconic structures, artworks and new cultural venues all address this crucial motivation. They are tangible demonstrations of a civic pride that, while reflective of the past, embodies a dynamic vision of the future.

Then there is the local authority officials, among them many of our most dedicated and driven public servants. While they are certainly not in the risk business, they do understand that our current economy is dependent on the free movement of goods, services and, ultimately, people. Cultural tourism, business gatherings and the establishment of new business bases are what drives our cities forward. Our purpose isto attract new business and retain good people.

Yet day-to-day tasks and extraordinary demands on ever-more finite resources inevitably become the focus of energy and endeavour, for councillors and officers alike. These concerns distract attention from the crucial need to constantly reinforce the significance of their particular place within an ever-changing and ever-more global, competitive economy. The evidence is there. Paris is the prime example, but Gateshead also presents a strong case. Local authorities must speculate to accumulate. The alterative to the enlightened patronage, which consolidates existing attractions and creates new ones, is stasis - or decline!

Getting local authorities on-side is a matter of persuading both the heart and the head. Great new buildings, excellent public spaces and 
streetscapes infused with works of art are a powerful boost to civic pride. They also undoubtedly help in the process of investment, bringing jobs and making our cities more interesting and pleasurable places in which to live.

Yet this gain is difficult to quantify. There is no empirical method of determining the impact of a monument. It might, like the Eiffel Tower, become the single most recognised major structure in Europe or it could, like the Atomium, be relegated to a very minor league in the tables of world tourism attractions.

However, there are some rules. Firstly, do not copy. Originality is fundamental. Secondly, embrace and endorse the really good idea, at least give it a chance. There is always the possibility that business or the lottery will contribute so that one will not have to bear all of the cost. Then there is the fact that one simply can not stand still. There are undoubtedly risks in taking on 'wow' projects. By far the greater risk is not taking them on and the inevitability of being left behind! 